\title{
Evaluation of Crop Storage Structures Utilization in Lagos State, Nigeria
}

\author{
Bankole, Y.O. \\ Taninola, O.A. \\ Adesina, B.S. \\ Department of Agricultural \& Bio-Environmental Engineering, School of Engineering, \\ Lagos State Polytechnic, Ikorodu-Nigeria
}

\section{Doi:10.5901/jesr.2013.v3n8p33}

\begin{abstract}
Nigerian farmers in general and those in Lagos State inclusive face multitude of challenges among which is large percentage of their crop yield lost due to poor handling and storage practices as determined by the type of storage structure used. Good storage practice when employed can reduce or completely eliminate crop losses. A survey was carried out through questionnaires and oral interviews to identify the type of storage structures employed in the four zones of Lagos State (Lagos Island, Lagos Mainland, Badagry, Ikorodu / Epe ). The outcome of the interviews and the questionnaires provided an insight into the problems experienced by the farmers in each zones which include, activities of insects, rats, birds, micro- organisms, pathogens and the interplay of some environmental conditions that could promote the activities of these agents of deterioration. Solution on how to reduce crop losses due to poor storage practices include disinfecting stores and cribs, using new bags, maintaining a moisture content favourable to crops during storage as well structural maintenance of silos, replacement of weak members in cribs and platforms and maintaining good ventilation in barns, rhombus and rooms to eliminate micro-organic activities were suggested.
\end{abstract}

Keyword: crop, storage, structures, losses, maintenance,

\section{Introduction}

Farmers all over the world lose much of their produce due to influence or activities of insects, rats, birds, micro- organisms, pathogens and the interplay of some environmental conditions that could promote the activities of these agents of deterioration. In Nigeria generally and Lagos State in particular farmers experience great losses of their farm produce. Alabadan (2006), reported that on-farm and post-harvest losses alone account for about $25-40 \%$ of the total crop yield in the country. To arrest the increasing losses, efficient storage structures or buildings that will minimize losses and maintain quality of stored produce is necessary and expedient.

Structure plays a critical role in agriculture, especially in the area of storing raw materials, finished product, equipment and livestock (Steffen, 2001). Structure is a body which is capable of resisting applied load without any deformation. Storage structure is any place or thing that is designed, fabricated especially to perform the function of safe keeping of produce. It can also be referred to as: all those facilities within and some far removed from an agricultural establishment, used for the storage of agricultural inputs and produce (Gwinner etal, 1990).

Crop storage structure may be an ordinary design or mere modification or remodeling of existing structures to perform the act of storage. It should be capable of maintaining the quality 
and quantity of the crop for as long as it is stored (Mijinyawa etal, 2006). An ideal storage structure therefore eliminates the destructive effects of weathering; loss of crop structure through dehydration (wilting and shriveling), germination of seeds or sprouting of tubers while in storage and loss of viability. In addition, the storage structure should be able to regulate environmental factors and provide an environment conducive for storage; easy to load and unload (Agboola, 1987); adequately storing to be self-supporting and to support load due to the stored produce, provide adequate security against pilferage (CAT and ACCT, 1987) and storage capacity enough to accommodate the amount of produce to be stored.

Temperature, relative humidity and ventilation regulation are environmental factors that affect stored produce in storage structure. Goldstein (2002) revealed that temperature in a storage structure normally should be kept within the range of about $1^{\circ} \mathrm{C}-27^{\circ} \mathrm{C}$ of the desired temperature for stored produce. A rise in temperature will cause an increase in enzymatic action and microorganism activities which may result in the rapid spoilage of stored produce unless some precautions are taken for their preservation. Enzyme activities speed up the decay of fruits and vegetables, micro-organism activities also speed up the loss in quality which results in chemical change of produce (change in color, texture and the amount of impurities) caused by bacteria, fungi and insect attack (Fordham and Biggs, 1985).

Relative humidity is the ratio of the actual amount of moisture present in an environment to the amount of moisture that would be required to saturate that environment at the same temperature (Goldstein, 2002). It is recommended that the relative humidity should be kept in the range of $70 \%$ for stored produce but for most perishable produce, the relative humidity structure should be kept at $90 \%$ - 100\%. Relative humidity close to $100 \%$ in atmosphere affect dry produce, promote fungus infection and contribute to the decay in the produce as a result of condensation. Relative humidity below this range is often utilized in hot climate to induce excessive evaporative loss of water. While ventilation rate is the exchange of air between an enclosure and the surroundings, the primary objectives of this may be for heat or moisture exchange or air purity. Ventilation rate are often selected; such that they are adequate to remove the moisture generated within the storage structure; this is often sufficient to control the accumulation of odour and removal of heat produced, such that the temperature within the structure can meet the requirement of the produce.

Over the years, considerable emphasis has been placed on increasing the efficiency of structures in order to improve on the availability of produce stored (Pedersen, 1978; Furtick, 1978) .Osagie (1992), classified crop storage structures as Improvised Storage Structures, Traditional Crop Storage Structure, and Modern Storage Structure

The utilization of the structures are based on the specific function each structure performs and it can be grouped into farm houses, building for crop production, building for product storage, building for processing, building for equipment and supplies and miscellaneous structures. Thus, the focus of the study is to review and describe the types of crops popularly stored and the storage structure commonly used in all the four zones of Lagos State; Lagos Mainland; Lagos Island; Badagry; and Epe/lkorodu, while specific objectives were:

- To identify the different types of crop storage and their uses in terms of agricultural produce.

- To evaluate the condition of crop storage structures and their level of usage

- To carefully look at the problem facing the storage structure and the possible solution aimed at improving their performance.

\section{Methodology}

The study populations were farmers in the four zones of Lagos State. Viz; Lagos Mainland; Lagos Island; Badagry; and Epe/lkorodu. A total of 135 farmers were sampled using questionnaires and oral interview as study instruments. Sixteen copies (16) of questionnaire were administered and 
thirty-five (35) oral interviews were conducted in Lagos mainland zone. Fourteen copies (14) of questionnaires were administered and twenty (20) oral interviews were conducted in Lagos Island zone. Six copies (6) of questionnaires were administered and fifteen (15) oral interviews conducted in Badagry zone. Nine copies (9) of questionnaires were admistered and twenty (20) oral interviews conducted in Epe/lkorodu. The total questionnaires distributed were forty-five (45) while all the oral interviews conducted were ninety (90), making a total of one hundred and thirty-five respondents in all the four zones.

\section{Results Presentation and Discussion}

The basic method of storage in Lagos Mainland zone is modern storage system. In the storage of cocoa bean, the crops were removed from the pods and cleaned manually. The produce were packaged into $60 \mathrm{~kg}$ jute sack at $17 \%$ moisture content, wet basis, and stored on iron pallet in warehouses. Some farmers stored same seeds packaged into various sacks which were weighed from the point of harvest and transferred. This can be stored for 3-4 weeks. After cleaning, the pure sesame seed were packaged into $50 \mathrm{~kg}$ paper sack and kept in warehouse for up to 3-4 months before processing. Oral interview were also conducted in some of the small scale level in the zone. Ventilated shed is used to store most perishable crops that include green pepper, cucumber and for about 3-4 days.

In Lagos Island, warehouses were used to store cashew nut at $16 \%$ moisture content and packed into $60 \mathrm{~kg}$ cloth sack placed on a wooden pallet for 1-3 months. But most of the farm enterprises visited in the zone embarks on the exportation of produce after storing them for about 1-3 months. Also respondents in some government storage centers and non-governmental organization use metal silo of different sizes for the storage of wheat, maize and barley at $14 \%$ $15 \%$ moisture content for about 1-3 months. Oral interview conducted revealed that some of the small scale storage level and farmers use unoccupied ventilated room to store shelled grain packed into $50 \mathrm{~kg}$ sack bag. The structure is also used to store any agricultural produce provided they are in a wholesome state.

Oral interview conducted in Badagry zone of the state revealed that small scale storage level farmers use unoccupied ventilated rooms to store hard hairy shell of coconut palm after removing the nut for about 4-5 months. This produce is also reported to be stored in a ventilated shed for 56 months. Questionnaires administered to some non-governmental organizations in the zone revealed the use of warehouse to store cocoa bean of $16 \%$ moisture content and packed into $60 \mathrm{~kg}$ cloth-sac placed on a wooden pallet for 1-3 months. The small scale farmers in the zone were also interviewed on the use of store grains. The structure is daily inspected to prevent insect infestation and moisture condensation. Rhombus structure is also used in the zone to store kola nut for about 4-5 months. The pods are removed and they are spread in the rhombus pot for storage.

Oral interview was conducted on the types of storage structures used. Farmers in Epe/lkorodu zone use woven basket for the storage of jute melon (Ewedu). Beds of growing vegetables are bought from the farmers before they are fully grown and when fully matured, they are harvested and sold immediately or kept for one or two days. Water is sprinkled at regular intervals on the vegetable at storage to maintain its freshness. Platform structure is used for the storage and drying of grains. The structure stored grain for 1-2 months and it is daily inspected to prevent insect infestation. For palm kernel, the palm fruits were plucked from the palm tree and kept on the floor under shed for about 3-4 days to finally ripe. For the storage of kola nut, rhombus is used in the zone and they can be stored up to five months without deterioration. Wooden crib is used by the small scale farmers to store corn still in cobs for 1-3 months. The structure was made from well treated wooden beam and columns with a corrugated iron roof sheet and walls made of wire netting. An occupied ventilated room is used to store harvested shelled dry grain packaged into $50 \mathrm{~kg}$ sack bag placed on a wooden pallet for about 1-3 months. 
Table 1. Types of Crop Storage Structures used by Large Scale Household Storage in the four zones examined

\begin{tabular}{lcccc}
\hline Storage structure & Lagos mainland & Lagos island & Badagry & Epe/lkorodu \\
\hline Warehouses & $35 \%$ & $30 \%$ & $10 \%$ & $10 \%$ \\
Cribs & $5 \%$ & $10 \%$ & $10 \%$ & $10 \%$ \\
Basket & $10 \%$ & - & $15 \%$ & $15 \%$ \\
Silo & $25 \%$ & $25 \%$ & $5 \%$ & $5 \%$ \\
Ventilated shed & $5 \%$ & $15 \%$ & $2-0 \%$ & $20 \%$ \\
Platform & $10 \%$ & - & $15 \%$ & $20 \%$ \\
Living room & $10 \%$ & $20 \%$ & $25 \%$ & $20 \%$ \\
\hline
\end{tabular}

Table 2. Categories of Storage Structures types used in different zones in Lagos State

\begin{tabular}{lcccc}
\hline Storage Structure & Lagos mainland & Lagos island & Badagry & Epe/lkorodu \\
\hline Improvised & $15 \%$ & $30 \%$ & $20 \%$ & $25 \%$ \\
Traditional & $10 \%$ & $5 \%$ & $70 \%$ & $65 \%$ \\
Modern & $75 \%$ & $65 \%$ & $10 \%$ & $10 \%$ \\
\hline
\end{tabular}
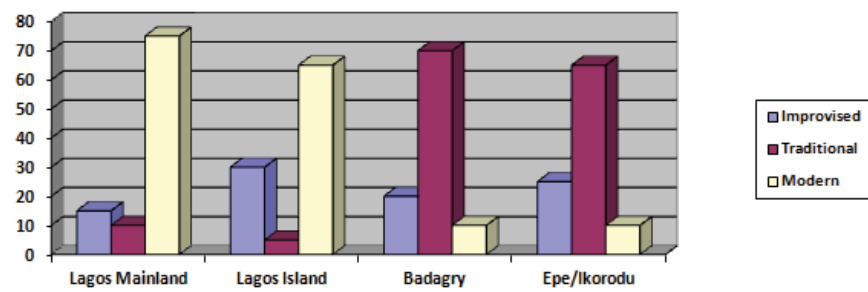

Fig.1. Storage structures types used in different zones of Lagos State
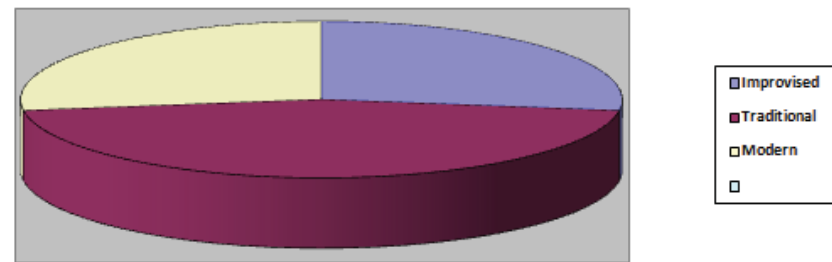

Fig.2. Usage of storage structures in different zones of Lagos State

Figure 1 depicts that Lagos mainland uses $15 \%$ of the improvised structure to store different produce like unoccupied ventilated room used for the storage of perishable crops e.g. water melon and cucumber for 1-2 days. About $25 \%$ of the improvised structure is used in Epe/lkorodu zone; unoccupied ventilated room to store palm kernel and shelled grain packaged into $50 \mathrm{~kg}$ sac bag. Ventilated shed is also used to store grains still in cobs for 2- 3 weeks. The structures also store produce for short period of days. Also, 30\% and 20\% of the improvised structure is used in Lagos Island and Badagry zones respectively to store carrot, water melon, coconut and sweet potatoes in ventilated shed. Lagos mainland uses $10 \%$ of the traditional structure to store dry grain for 1-2 weeks and basket to store vegetables for 1-2 days. About $65 \%$ of traditional structure is used in Epe/lkorodu zones to store grains and sliced yams for 2-3 weeks. Basket is also used to store vegetable and jute mallow while crib structure is used to store maize cobs for 2-3 months. Lagos Mainland, Lagos Island and Badagry/Epe/Ikorodu use about 75\%,65\% and $10 \%$ respectively of modern structure; warehouse to store cocoa bean, seed and cashew nut in their large quantities for more than 4 months. Silo structure is also used to store barley, wheat sorghum and maize at 
different moisture content for about 2-3 months.

Table 1, depicts that crop storage in the state is done at two levels. Large scale is done using silos and warehouses while small scale storage is done using various types of structures; basket, platform, cribs, shed and unoccupied room. The study revealed that $90 \%$ of the large scale storage was used in Lagos Mainland and Lagos Island zones compared to the level of storage in Epe/Ikorodu and Badagry zones. Figure 3, reveals some of the problems experienced with some of the storage structure in the state, about $60 \%$ of the ware house had problems of roof leakages and about $70 \%$ of the produce stored in them were attacked by rodents causing loss in produce quantity. Moreso, about $40 \%$ of platforms were reported to be bent sometimes collapsing due to overloading and about $50 \%$ of the produce stored in them were exposed to insect infestation causing loss in quality to store produce.

Table 3. Problems Associated with some Storage Structures in the Zones.

\begin{tabular}{lccccc}
\hline & Leakages & Collapse & Bending/Bucking & Rusting & Joint failure \\
\hline Warehouse & $70 \%$ & - & - & - & - \\
Crib & $20 \%$ & $25 \%$ & $20 \%$ & $30 \%$ & $20 \%$ \\
Basket & - & - & $10 \%$ & - & - \\
Silo & - & - & - & $70 \%$ & $80 \%$ \\
Platform & - & $40 \%$ & $40 \%$ & - & - \\
Living room & $10 \%$ & - & - & - & - \\
Shed & - & $35 \%$ & $30 \%$ & - & - \\
\hline
\end{tabular}

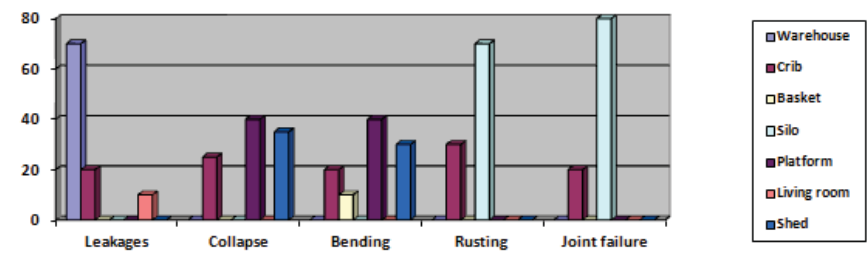

Fig.3. Problems associated with some storage structures in the zones.

\section{Conclusion and Recommendations}

Lagos state was divided into four zones, Lagos mainland, Lagos Island, Badagry and Epe/lkorodu, where crop storage structure employs two levels. Large scale storage uses silos and warehouse while the small scale storage uses various types of structures; basket, platform, crib shed and ventilated room. Some of the problems associated with the various storage structure at both small scale and large scale storage in all the zones include moisture penetration, rusting, molding and caking in silo; bag tearing by rodents and leakages in warehouse roof; insect infestation and rodent attack in woven and ventilated room; bending and collapsing of platform, ventilated shed and crib. However, measure towards solving the problems include the use of weevil and fumigant tablet for produce and storage crops; replacement of rusted and broken part; replacement of broken roofing sheet in warehouses; the use of treated poles to replace the weak members in crib and platform and the reconstruction of the entire structure after- three years of usage.

Following the submissions in the study, the following recommendations were suggested:

1. Warehouse should be fumigated with required chemicals and other storage structure should be thoroughly cleaned and disinfected immediately they are empty and just before storing produce.

2. The silo structure should be structurally maintained by minimizing rusting and eliminating cracking thereby maintaining the quality of stored produce throughout the storage period. 
3. The use of rat guards and the use of treated poles and poles of bigger sizes to replace the weak members in cribs and platform should be vigorously promoted in order to minimize post-harvest losses.

4. The barn, rhombus and unoccupied living room should be well ventilated in order to enhance the exchange of air between an enclosure and the surroundings thereby eliminating the enzymatic action and micro-organism activities which result in the rapid spoilage of stored produce.

\section{References}

Agboola, S.D. (1987). Cocoyam storage and its potential for food sufficiency and future economic recovery of Nigeria. National Root Crops Centre.Federal Department of Agriculture, Umudike, Nigeria.

Alabadan, B.A. (2006). Evaluation of wooden silo during storage of maize in humid tropical climate. Agricultural Engineering International: The CIGR Ejournal. Manuscript BC 05013. Vol. VIII.

CAT and ACCT (1987): The storage of food grains and seed. Macmillan Press Ltd, London.

Fordham, R. and Biggs, A. (1985). Principle of vegetable crop production. William Collins and Sons, London Publisher.

Furtick, W.R. (1978). Weeds and world food production. Published by west view press 5500 central Avenue, Wishington, D.C New York

Gwinner, J., Harnisch, R. and Muck, O. (1990). Manual on the prevention of post harvest grain losses. Pickhuben 4, Hamburg Publisher.

Goldstein, M. (2002). The complete idiot's guide to weather. Alpha Books-Penguin Group (USA) Inc.

Mijinyawa, Y., Mwinjilo, M. and Dlamini, P. (2006). Assessment of crop storage structure in Swaziland. Agricultural Engineering International: The CIGR Ejournal. Invited Overveiw No 22. Vol VIII

Osagie, A.U (1992). Yam tuber in storage. Pentnogbe Publishing Company Ltd, Benin City.

Pedersen, J.R. (1978). Post harvest food losses. West View Press 5500 Central Avenue, Washington, D.C. New York.

Steffen, O. (2001). The role of agricultural structure in safety and health issues. National AG. Safety Database; Southern Illinois University. 